\title{
European Integration of Georgia and Financial- Economic Condition: Achievements and Challenges
}

\author{
George Abuselidze ${ }^{1}$, Doctor of Economics, Professor
}

\begin{abstract}
The work deals with the peculiarities of Georgia-EU relations; Current and future opportunities that the European Union and European integration offers to Georgia have been studied; The study uses statistical data, international organizations research and data from political documents. The possible difficulties that Georgia can create in the economic integration process are analyzed. The author's opinions about the existing problems and the ways of their overcoming are expressed and proved with arguments. Finally, based on the results obtained from the research, the author's recommendations are established.
\end{abstract}

Keywords: European integration; Deep and comprehensive trade agreement; Foreign Direct Investment; Money transfers; Foreign trade turnover;

\section{Introduction}

European integration as a strategic goal and process is a very important result for Georgia, the right to free movement of people allows Georgia to be a second country from the Eastern Partnership countries, after Moldova, whose citizens are entitled to visa free travel in Schengen space. This positive influence also affects the relations between people, which in turn strengthens European values in Georgia. Causes the formation of a trading system compatible with the EU market; Increase the attractiveness of the investment environment and encourage foreign investment; Create new jobs as a result of stimulating foreign investments; Increase of competitiveness of Georgian products; Increase of Georgian exports; Improvement of quality of Georgian products; Stimulating economic growth and economic development of Georgia in general (Ministry of Economy and Sustainable Development of Georgia, 2014).

The existence of deep and comprehensive free trade space with the EU positively affects on the prospects of integration into the world market, the existence of a global supply network and in turn gives entrepreneurs new business opportunities. That is why it is appropriate to investigate whether the globalization process is compatible with the protection and strengthening of sovereign and small countries' economic security (Abuselidze, 2012).

\subsection{The purpose and objectives of the work}

The goal of the work is to analyze the main stages of development of GeorgiaEU relations, major economic achievements and existing challenges. The work is an attempt to set the main tasks on the background of Georgia's ongoing integration with the European Union and develop recommendations that will be fulfilled and will speed up Georgia's trade-economic and financial-credit integration process. An analysis of the

${ }^{1}$ Head of Finance, Banking and Insurance Department, Batumi Shota Rustaveli State University (Georgia). 
importance of the European integration and the possibilities that the Union offers to Georgia's economy, analysis of possible obstacles and challenges in parallel with this process.

\subsection{Theoretical value of the work}

The work is innovative in terms of its approaches and recommendations, as well as in a new perspective of researching topics. The issues and provisions given in it may be used to analyze existing theoretical positions. In addition, the theoretical significance of the thesis is that the issues discussed in it and the expressed opinions are polemic and requires deeper research. Consequently, it can become a motif and a major base for further studies in the given direction.

\subsection{Practical meaning of the work}

Practical realization of the conclusions, recommendations and proposals received as a result of the research will facilitate financial stability and economic growth in parallel to the country's European integration. It is great base for Increasing population revenues, attraction of investments and completion of diversified and credible source formation of financing.

\section{Problem Formulation and Methodology}

\subsection{Research methodology}

The paper uses research assessment and quantitative methods, more specifically, system analysis method, as a result, the study material is divided into parts, and the next stages cover each part's assessment and include final results. Statistical data, tables and diagrams are used to analyze and conclude the issue within the quantitative method of research.

\subsection{Peculiarities of Georgia's Financial and Economic Integration in the European Union}

The ongoing integrative processes in the world are irreversible, offering small challenges, along with significant opportunities and small challenges.

Access to the EU's one of the largest and richest markets in the world is a strong impetus for diversification and development of Georgian business, local production and export. There is a significant basis for the growth of Georgia's attractiveness for direct foreign investments, which, in turn, will facilitate the introduction of new technologies and know-how, stimulating the emergence of competitive local produce and creating jobs, it will help to form trading system compatible with the EU market, create new jobs as a result of stimulating foreign investments, increase export, improve quality and stimulate growth of economy.

Georgia-EU relations started from the independence of Georgia. The EU appeared on the South Caucasus stage in the early 90s. In the period when the countries took the first steps towards market economy and democracy (Fischer, et al., 1996). According to Bartlett et al. (2017), Since the beginning of the 1990s and the transformation of the former socialist countries, interest in the quality of institutions as a determinant of economic growth has increased considerably. 
Since 1995, Georgia benefits from the EU's Generalised System of Trade Preferences (GSP), but since 2005 it was the EU's Generalised System of Preferences (GSP + trade regime) and now, country benefits from Deep and Comprehensive Free Trade Agreement (DCFTA) that was officially signed in 2014. The Deep and Comprehensive Free Trade Agreement (DCFTA) signed between Georgia and the European Union in 2014 is the largest free trade agreement that has made the European Union available to any country (Michael, 2016). On 22th April of 1996, the European Union and Georgia signed a Partnership and Cooperation Agreement (PCA), in Luxemburg. On September 1, 1997, in accordance with the decision of the Parliament our country started harmonization of legislation according to the EU's demands (Abramishvili, 2016).

Economic integration is accompanied by a process of trade-economic and financialcredit integration, so it is necessary to analyze and discus about important issues of foreign economic relations such as: Foreign trade, foreign money transfers and investments (Putkaradze, 2017).

According to Guiso et al. (2004), the financial integration is bound to accelerate the development of the most backward financial markets and to allow companies and households from these countries to access the credit and security markets of the more advanced countries of the Union. The same author claims that the recent theoretical and empirical literature demonstrates that financial development is associated with higher economic growth, and economists and policy makers expect financial integration to have a "growth dividend" in Europe (Vyklyuk et al., 2013). According to Vukovic et al. (2017), Financial integration is fundamental for Europe. It ensures that its economy remains internationally competitive and continues to prosper, which in turn is essential for maintaining the EU's political legitimacy (Grossman \& Leblond, 2011).

According to Vukovic et al. (2017), recent decades showed that financial integrations in the European Union (EU) gave excellent results. Grossman and Leblond (2011) argue that the recent history of financial integration in Europe can generally be considered a success story. Grahl and Teague (2005) claim that the financial integration policies launched by the EU are a remarkable success. According to McCreevy (2006), Europe has made "real progress" on financial integration.

\subsubsection{Investment environment}

In Georgia, special importance is given to the investment attractiveness of the country and the liberal investment policy, association Agreement with the European Union and new perspectives, favorable geographical location and many other factors create a firm basis for starting a business in Georgia and for its successful development. 


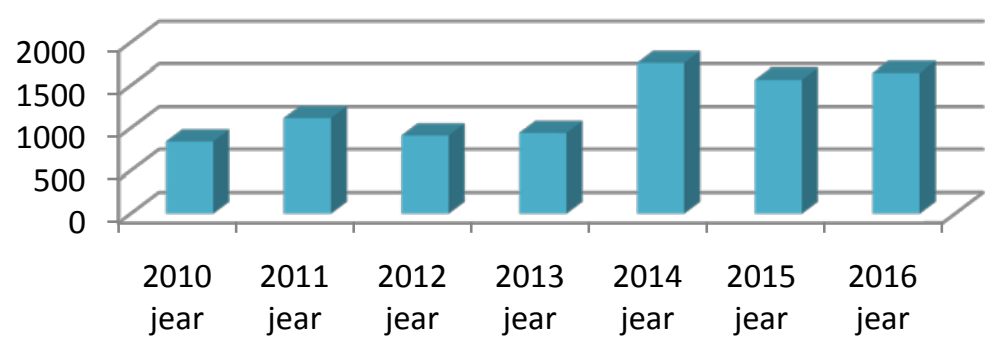

Figure 1: Foreign Direct Investment in Georgia

Source: http:// forbes.ge/news/1943/2016-wels-pirdapiri-ucxouri-investiciebi-gaizarda

According to the data of the Department of Statistics of Georgia, foreign direct investments made in Georgia from 2006 to 2016 are about 14 billion US dollars. Foreign Direct Investment - FDI in Georgia in 2015 amounted to 1564 million US dollars, which is 11 percent lower than the corresponding figure of 2014, while the volume of direct foreign investments in Georgia in 2016 is 1645 million US dollars which is 5 percent more than in 2015. In the year 2017, foreign direct investment in Georgia amounted to \$1 862 million, accounting for 16.2\% (\$259 million) in 2016 (National Statistics office of Georgia, 2017).

At the same time, the International Financial Institution (EBRD), which has existed since 1991, is actively involved in the former Soviet Union countries, financing both private and public sector projects and promotes sustainable economic and democratic development of the countries.

The European Bank for Reconstruction and Development in strategic document EBRD (2018) developed in December 2016 allocates 4 central investment directions in Georgia:

- $\quad$ Funding of innovative projects in the private sector with the standards set out in the Deep and Comprehensive Free Trade Area Agreement (DCFTA) with the European Union;

- $\quad$ Financing of commercial banks' financial assistance projects;

- Funding of Georgia's transient potential strengthening projects in the region;

- $\quad$ Financing of Georgia's energy efficiency projects.

The first funding of Georgia in the Investment Archive of the European Bank for Reconstruction and Development (EBRD) was fixed on 23 October 1996 - 4 million euros given to Absolute Bank. In the year 2000, EBRD has implemented an equivalent amount of $€ 165$ million in Georgia. In 2001-2002 the bank suspended investment activities in Georgia. The volume of investments made from 2003 to 2016 is 2.8 billion euros. From the date of its arrival to 2016, EBRD has issued 3 billion euros in 201 projects implemented in Georgia. 41\% of the total amount was spent in energy sector, $27 \%$ in the industry, trade and agriculture, $24 \%$ in the financial sector and $8 \%$ for infrastructure projects. From 2010 to 2016, EBRD has invested 860 million euros in Georgia. During this period, the largest investments - 248 million euros were made in 2016 (European Bank, 2018). 


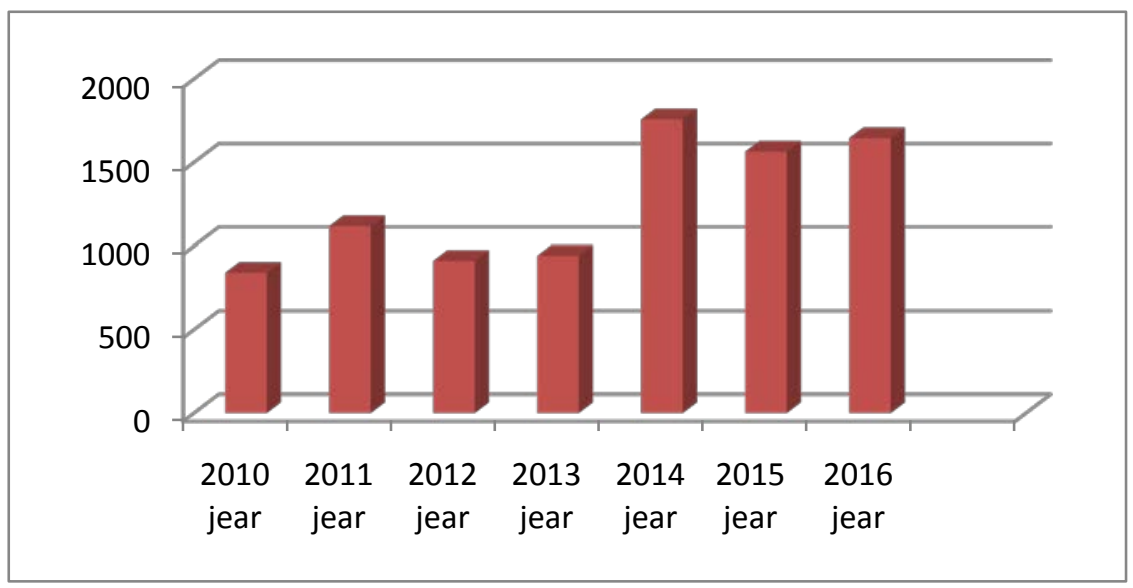

Figure 2: The volume of investments made by EBRD in Georgia, 2010-2017 (EUR million)

Source: http:/ / factcheck.ge/article/ sagarthveloshi-gankhortsielebuli-investitsiebis-kuthkhith-2016-tseliebrd-isthvis-sarekordo-ighol

The European Bank for Reconstruction and Development (EBRD) started to work in Georgia in 1996 and invested a total of 3 billion euros. 91\% of these are private and 9\% in the public sector.

Although recent foreign direct investment rates are characterized by a growing tendency in Georgia, but according to recent dat of International Business Compass 2018 survey, which deals with the investment environment of the world, has not changed its position and is still in the 47 th place. The goal of the research is to determine how attractive the country is to the private sector investment. According to the survey, Georgia's rating score is 60.43 from 100. The study includes three indicators: economic, political-legal and socio-cultural. Georgia is in the 41 th place with 73 points in the political-legal indicator, which is a deterioration of 5 positions compared to the previous year (Hüning, et al., 2017). The country is ranked 53th on socio-cultural criteria, while the economic environment is estimated at 57. Last year Georgia was ranked 48th on the economic environment criterion. 
Table 1: INDEX RANKINGS 2017

\begin{tabular}{|c|c|c|c|c|c|c|c|c|c|c|}
\hline \multirow[t]{3}{*}{ Country } & \multirow{3}{*}{$\begin{array}{l}\text { Conti: } \\
\text { nent }\end{array}$} & \multirow{2}{*}{\multicolumn{3}{|c|}{ Index }} & \multicolumn{2}{|c|}{ Economic } & \multicolumn{2}{|c|}{ Poirico-legai } & \multicolumn{2}{|c|}{ Socio-cultural } \\
\hline & & & & & \multicolumn{6}{|c|}{ Framework conditions } \\
\hline & & Rank & Change & Value & Rank & Value & Rank & Value & Rank & Value \\
\hline Latvia & EU & 37 & 2 & 62.72 & 31 & 59.70 & 33 & 76.58 & 63 & 53.97 \\
\hline Hungary & EU & 38 & 7 & 62.55 & 38 & 58.05 & 44 & 72.67 & 49 & 58.01 \\
\hline Slovakia & EU & 39 & 4 & 62.41 & 36 & 58.93 & 38 & 74.73 & 57 & 55.20 \\
\hline Italy & EU & 40 & -5 & 62.36 & 45 & 56.35 & 45 & 72.41 & 39 & 59.43 \\
\hline Malaysia & AS & 41 & -5 & 62.35 & 37 & 58.74 & 53 & 67.07 & 33 & 61.53 \\
\hline Kuwait & AS & 42 & 4 & 62.31 & 21 & 62.37 & 76 & 58.56 & 22 & 66.24 \\
\hline Spain & EU & 43 & -1 & 61.67 & 44 & 56.80 & 28 & 78.78 & 75 & 52.41 \\
\hline Saudi Arabia & AS & 44 & 6 & 60.94 & 23 & 62.14 & $n$ & 58.37 & 32 & 62.39 \\
\hline Portugal & EU & 45 & .5 & 60.73 & 52 & 54.46 & 25 & 79.81 & 82 & 51.53 \\
\hline Samoa & $O C$ & 46 & -2 & 60.63 & 74 & 50.85 & 54 & 66.95 & 23 & 65.47 \\
\hline Georgia & AS & 47 & 0 & 60.43 & 57 & 53.94 & 41 & 73,37 & 53 & 55.76 \\
\hline Uruguay & LAM & 48 & 1 & 59.96 & 70 & 51.13 & 24 & 79.90 & 72 & $\$ 2.77$ \\
\hline
\end{tabular}

Source: BDO INTERNATIONAL BUSINESS COMPASS 2017

https:// www.bdo.ge/getattachment/Insights/Publications/BDO-IBC-International-Business-Compass2017/BDO IBC17 EN web.pdf.aspx?lang=en-GB

Table 2: INDEX RANKINGS 2018

\begin{tabular}{|c|c|c|c|c|c|c|c|c|c|c|}
\hline \multirow[t]{3}{*}{ Country } & \multirow{3}{*}{$\begin{array}{l}\text { Conti- } \\
\text { nent }\end{array}$} & \multirow{2}{*}{\multicolumn{3}{|c|}{ Index }} & \multicolumn{2}{|c|}{ Economic } & \multicolumn{2}{|c|}{ Dolitical-1egal } & \multicolumn{2}{|c|}{ Socio-cultural } \\
\hline & & & & & \multicolumn{6}{|c|}{ General conditions } \\
\hline & & Rank & Change & Value & Rank & Value & Rank & Value & Rank & Value \\
\hline Barbados & LAM & 38 & 13 & 60.00 & 65 & 50.41 & 29 & 78.83 & 50 & 54.36 \\
\hline Latvia & EU & 39 & 0 & 59.99 & 34 & 55.68 & 33 & 77.31 & $\pi$ & 50.14 \\
\hline Portugal & EU & 40 & 3 & 59.51 & 49 & 52.54 & 26 & 79.27 & 73 & 50.59 \\
\hline Lithuania & EU & 41 & -3 & 59.48 & 32 & 56.03 & 25 & 79.53 & 94 & 47.22 \\
\hline Spain & EU & 42 & 0 & 59.43 & 37 & 54.80 & 35 & 76.36 & 76 & 50.16 \\
\hline Slovakia & EU & 43 & -3 & 59.37 & 41 & 5419 & 39 & 74.15 & 61 & 52.08 \\
\hline Samoa & $O C$ & 44 & 4 & 59.20 & 70 & 49.50 & 53 & 66.41 & 23 & 63.11 \\
\hline Hungary & EU & 45 & -4 & 59.15 & 56 & 5212 & 41 & 72.67 & 46 & 54.64 \\
\hline Kuwait & AS & 46 & -2 & 58.68 & 31 & 56.04 & 82 & 57.40 & 24 & 62.80 \\
\hline Ceorgia & AS & 47 & 3 & 5836 & 48 & 52.56 & 46 & 71.42 & 56 & 52.95 \\
\hline Mauritius & Af & 48 & -2 & 5785 & 83 & 48.38 & 30 & 78.79 & $n$ & 50.79 \\
\hline Uruguay & LAM & 49 & -4 & 5771 & 104 & 46.62 & 31 & 78.07 & 57 & 52.80 \\
\hline Saudi Arabia & AS & 50 & -1 & 56.65 & 26 & 56.46 & 83 & 55.69 & 36 & 57.82 \\
\hline
\end{tabular}

Source: BDO INTERNATIONAL BUSINESS COMPASS 2018

file:///C:/Users/Lenovo/Downloads/BDO_IBC_2018_EN_20180524_v4.pdf

Taking into consideration the above mentioned, it is necessary to ensure the integrity and liberalization of the investment policy in order to improve Georgia's European integration process. It is necessary to take more efficient measures to attract European (and not just) investments. 


\subsubsection{Condition of Money Transfers}

An important issue that requires deep analysis is money transfers in the integration process. The value of money transfers is even higher for developing countries, because for many families living there money transfers are main source of income. According to the World Bank, since 2000, the number of money transfers in the world is growing steadily. Their volume is almost equal to the amount of direct foreign investments and significantly exceeding foreign aid received by developing countries.

For February 2015, the amount of money transferred from Russia is 28170 million dollars, Greece is in the second place with 13726 million dollars, Italy occupies third place with 8957 million dollars, in the same period, one of the key factors of Lari's devaluation was to reduce the volume of transfers, which led to the Russian-Ukrainian conflict and the economic crisis in these countries.

$>\quad$ Reduction of transfers negatively affects economic activity. This is especially noticeable on the background of impaired negative balance sheet and depreciation of the national currency exchange rate.

Transfers from Russia has been significantly reduced since 2015, the Russian ruble has been significantly diminished and Russia's economy is facing problems due to sanctions.

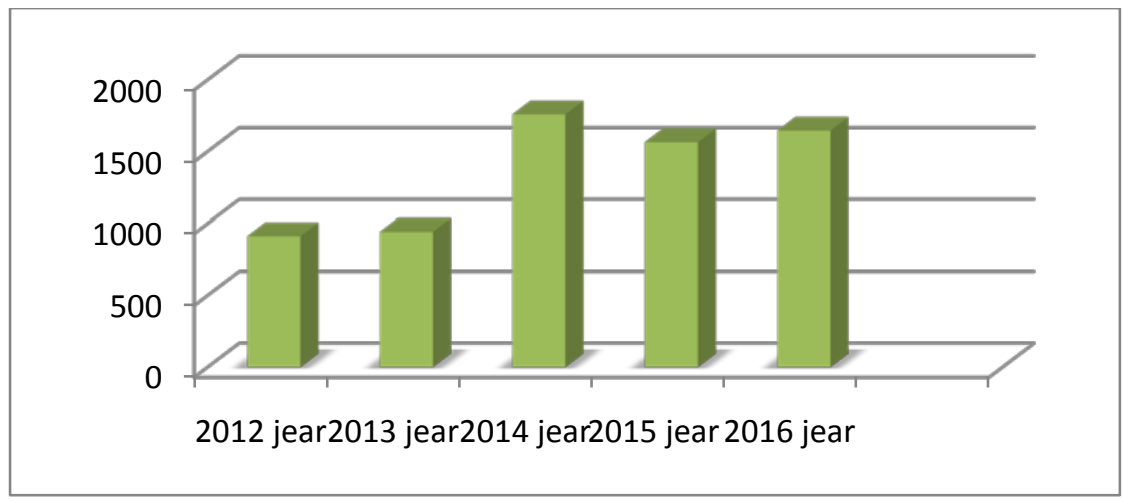

Figure 3: The volume of transfers received from Russia

Source: author

During the year 2016, in the form of money transfers in Georgia 1.15 billion US dollars, which is $6.6 \%$ more than the previous year. By 2017, this indicator will be 1.24 billion dollars, in the first half of 2018, employers in the EU countries transferred over \$ 41 million as money transfers in Georgia. In January-June, 255 million dollars from the European Union and 214 million dollars from Russia were transferred. So far more money has been sent from Russia than from EU territory. Monetary remittances from Russia are cut by an average of 0.5 million dollars a month, and the EU withdraws from month to 11 million dollars (Forbes Georgia, 2018). 


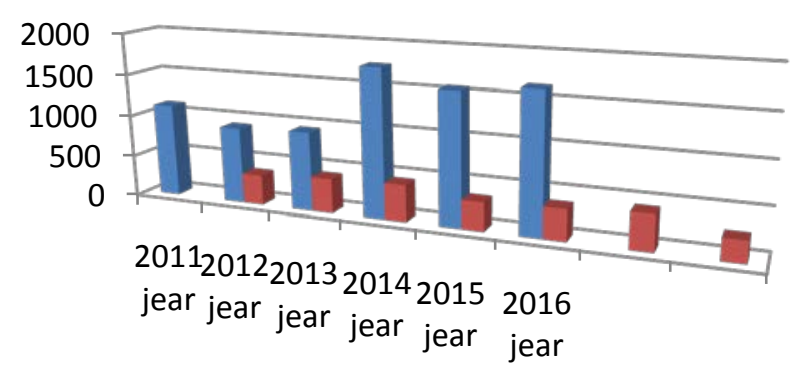

Figure 4: Money transfers from the EU and Russia, million dollars

Source: Forbes Georgia, http:/ / forbes.ge/ news/4451/ evrokavSirma-ruseTs-gadauswro

The most from the the EU countries are sent from Italy, Greece, Germany and Spain.

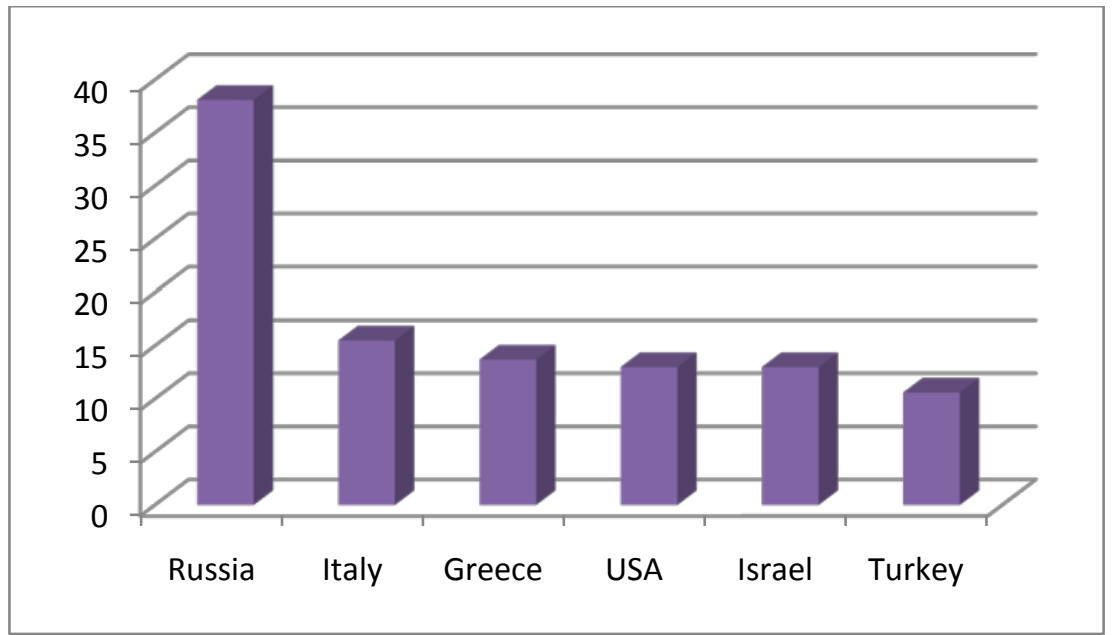

Figure 5: Volume of Money Transfers (Million USD)

Source: bttps:/ / m2b.ge/post/197835-fuladi-gzavnilebis-moculoba-17-it-gaizarda-

As we see in Russia, Ukraine and Greece, the processes in the country can cause a sharp decline in the volume of money transfers, which negatively impact Georgia's economy. According to the current data, the CIS countries, especially Russia, therefore, for the purpose of diversification of risks, the country needs to find alternative and stable ways of receiving remittances as a priority.

The community and the state have a more serious approach to the issue of money transfers. It is very important to understand the impact and importance of money transfers and search for the ways of forming more efficient policies for management of transfers. It should be taken into consideration that the number of transfers in Georgia exceeds the flow of grants and direct foreign investments, which once again emphasizes it as a strategically important factor for the development of our country.

Money transfers are an important source of foreign currency inflow that allows the purchase of imported goods, allows to pay foreign debts, at the same time, the 
country is more protected and is less susceptible to foreign shocks. In addition, in contrast to other foreign sources of direct foreign investment and development assistance, money transfers are not characteristic to the repayments of percent debt or dividends. Depending on the foregoing, the state should strive to increase the share of EU countries in foreign remittances, and on the way to European integration, make money transfers as potential means of growth.

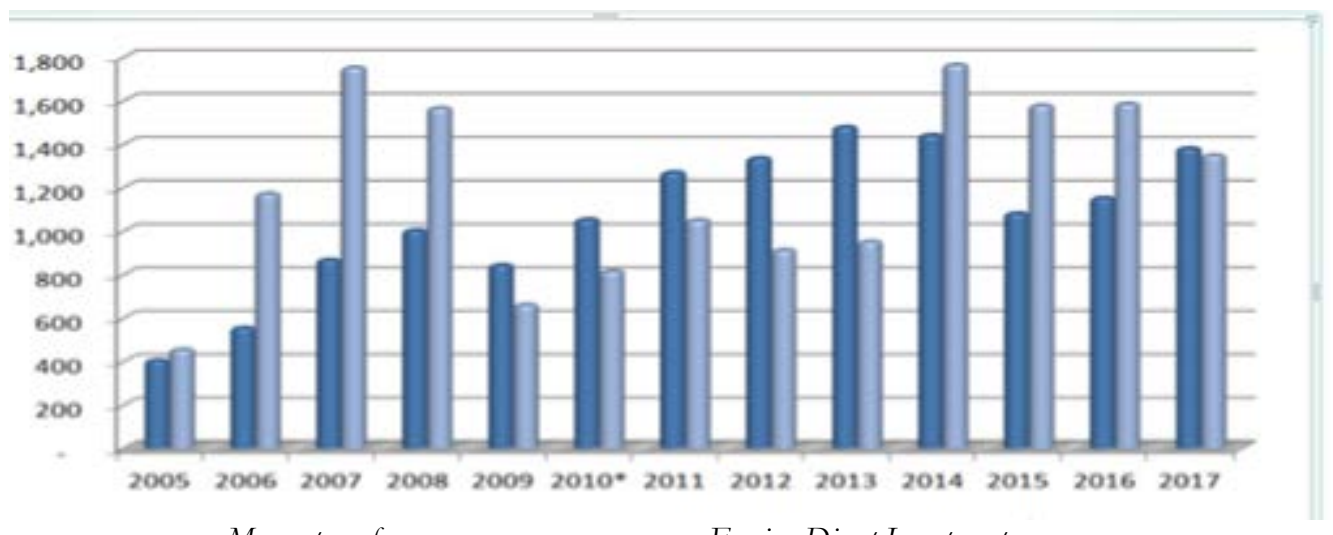

Money transfers

Foreign Direct Investments

Figure 6: Dynamics of money transfers and foreign investments (Million USD)

Source: http:/ / eugeorgia.info/ ru/article/ 730/ rogor-unda-iqces-emigrantebis-fuli-investiciebad

\subsubsection{Foreign trade}

Leveraging trade and integration into world leading markets is the main priority of Georgia's foreign policy, today, the country has one of the most liberal trade policies in the region, which is reflected in simplified foreign trade regime and customs procedures, low import tariffs and minimum non-tariff regulation. Foreign trade trends in Georgia show negative trade balance.

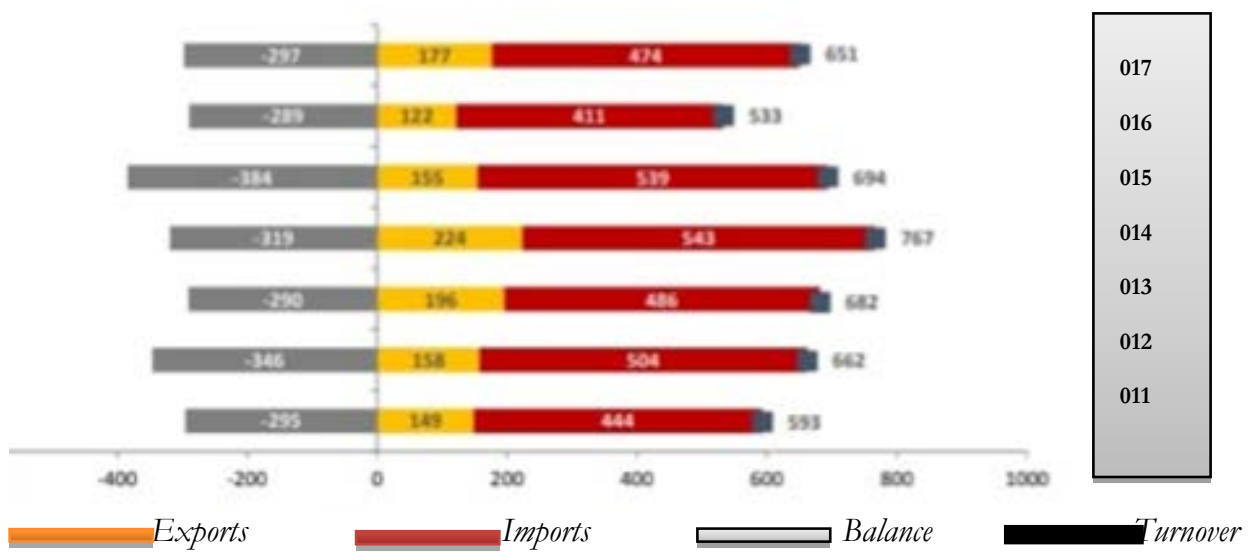

Figure 7: Foreign Trade (Million USD) Source:

bttps:// www.mof.ge/ images/File/BROSHURA/2017/Outlook_February_GEO-17.pdf 
According to the data of 2013, Georgia's foreign trade turnover increased by $6 \%$ in 2012 and was 10784 million US dollars. Export increased by 22\% and was 2909 million US Dollars. While import increased by $0.4 \%$ and was 7874 million US dollars. Georgia's negative trade balance was 4965 million. US dollar improved by $9.1 \%$ compared to the previous year and made $46 \%$ of the foreign trade turnover. The number of Georgia's trade partner countries has been defined by 134 countries. From this, positive trade balance was observed with 40 countries (Ministry of Economy and Sustainable Development of Georgia, 2013).

In 2014 Georgia's foreign trade turnover increased by 4\% with EU countries, amounting to 2990 million USD and occupied 26\% of Georgia's trade turnover:

- Export increased by $2 \%$ was $\$ 621$ million and occupied $22 \%$ of total exports;

- Import increased by 4\%, amounted to 2369 million USD and occupied 28\% of total imports (Ministry of Economy and Sustainable Development of Georgia, 2014).

Georgia's foreign trade turnover for January-June 2015 has decreased by 13\% compared to the same period of 2014 and was determined by 4761.2 million US dollars. Exports amounted to 1081.6 million USD and decreased by $24 \%$ compared with the same period last year, while imports amounted to $\$ 679.6$ million and decreased by $9 \%$ compared to the same period last year.

At the same time, Georgia's foreign trade turnover increased by $2 \%$ in January-June 2015.

- $\quad$ Export fell by $2 \%$ to 293 million US dollars

- Import was increased by 3\% and were 1141 million USD (Ministry of Economy and Sustainable Development of Georgia, 2015).

In 2016, Georgia's foreign trade turnover amounted to 11966 million USD, which is $20 \%$ more than the previous year.

- $\quad$ Exports decreased by 4\% and reached \$ 114 million

- Imports increased by $27 \%$ and amounted to 9852 million USD

Negative trade balance amounted to 7738 million USD and 65\% of trade turnover.

In 2016, Georgia's external trade turnover increased by 14\% compared to 2015, export was reduced by 12\%, amounted to 571 million USD and occupied $27 \%$ of total exports. Import was increased by 20\%, 3030 million USD and 31\% of total imports (Ministry of Economy and Sustainable Development of Georgia, 2016).

Georgia's foreign trade turnover increased by 13.8\% in 2017 and amounted to 10707.4 million USD.

- $\quad$ Exports increased by $29.1 \%$ and amounted to 2728 million USD;

- Imports increased by $9.4 \%$ and amounted to 7979.4 million USD;

- $\quad$ The trade balance amounted to 5251.1 million USD and 49\% of foreign trade turnover.

Trade turnover increased by 2\% to USD 2844 million and occupied Georgia's trade turnover of $26.6 \%$, exports increased by $13 \%$ and imports decreased by $0.8 \%$ compared to the same period last year (Ministry of Economy and Sustainable Development of Georgia, 2017). 


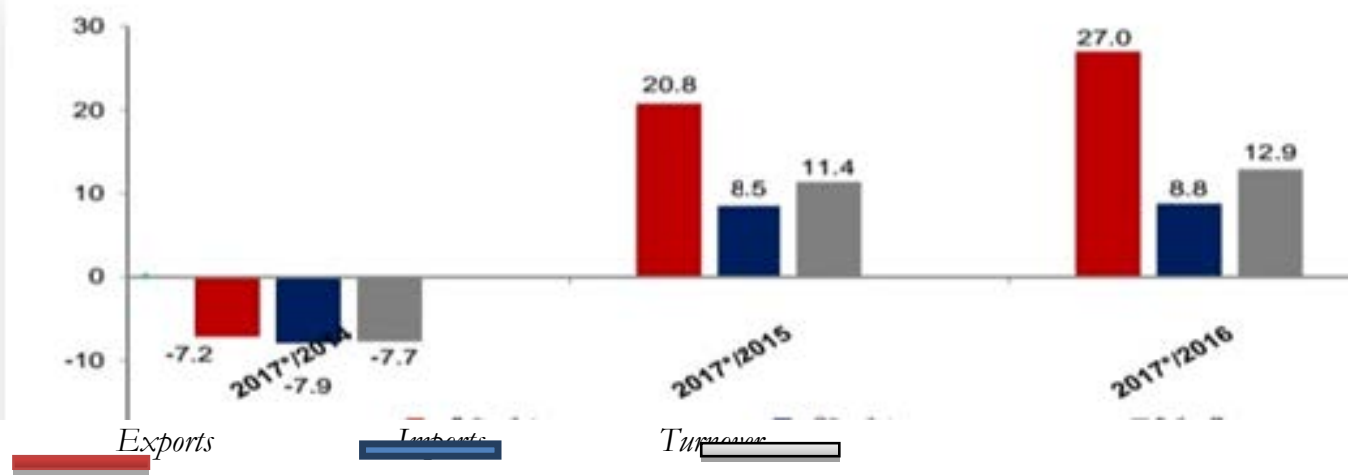

Figure 8: Change of Foreign Trade Indices in January-November of 2017 compared to the corresponding period of previous years (\%)

Source: Georgia National Statistics Office

http:// www.geostat.ge/cms/site_images/_files/georgian/bop/FTrade_11_2017_GEO-

with\%20cover.docx.pdf

Based on the foregoing, the foreign trade trend of 2012-2017 is following:

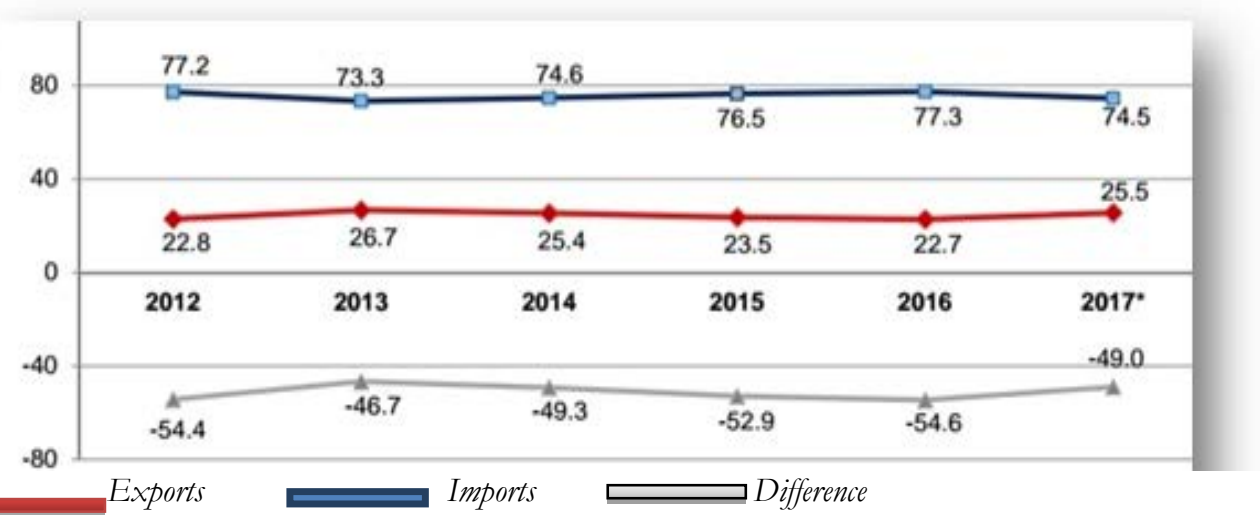

Figure 9: Share of Foreign Trade Indicators of Turnover (\%) of January-November 2012-2017

Source: National Statistics Office

http:// www.geostat.ge/cms/site_images/_files/georgian/bop/FTrade_11_2017_GEO-

with\%20cover.docx.pdf

While foreign trade, particularly export share, looks as follows in EU countries: 


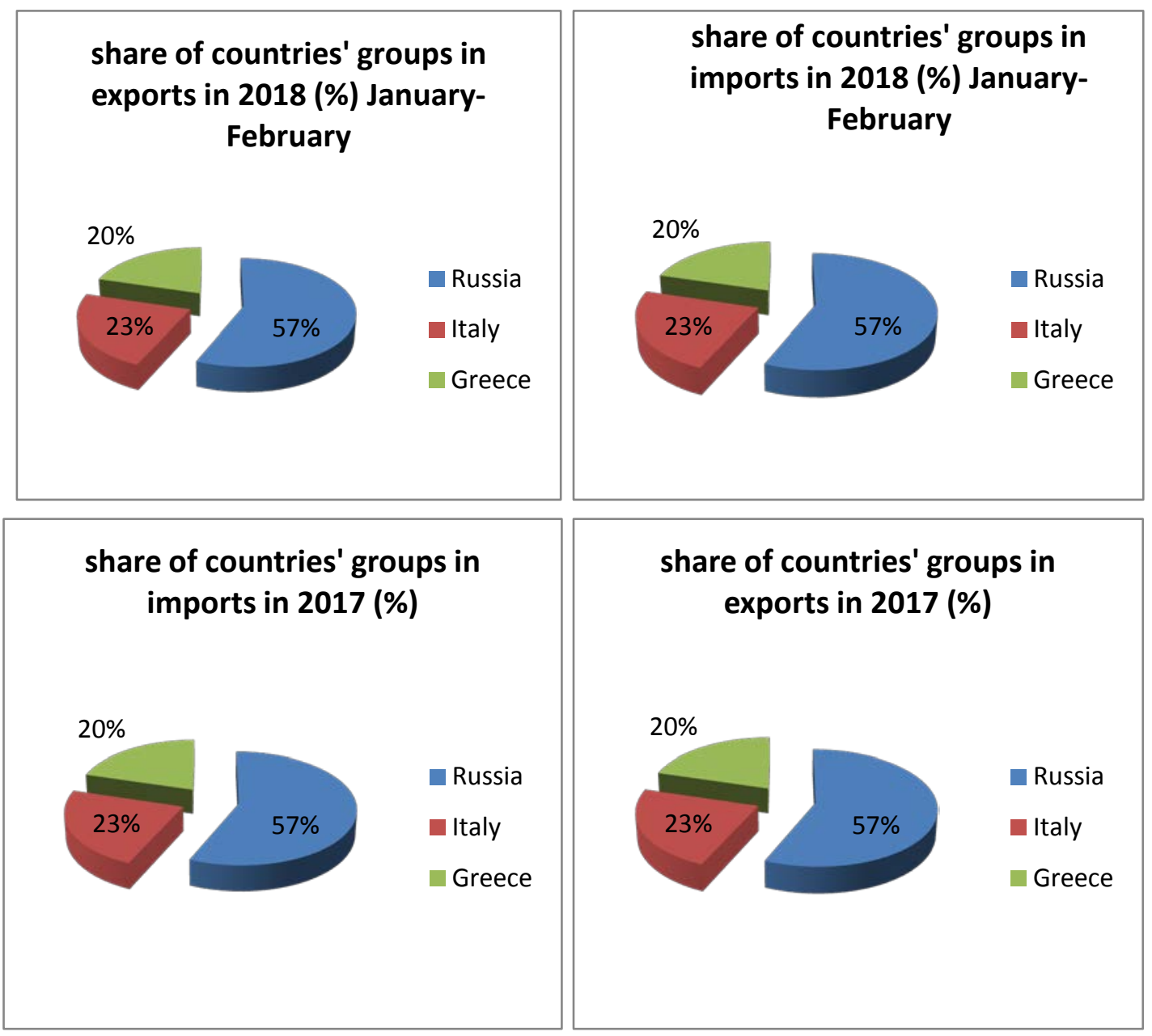

Figure 10: The share of countries in export / import 2017-2018 year Source: National Statistics Office

http://wmw.geostat.ge/cms/site images/ files/georgian/bop/FTrade 112017 GEO-with\%20cover.docx.pdf

From the United National Statistics Office (National Statistics office of Georgia, 2017), the trade turnover between Georgia and the EU member countries has been observed, However, the extent of the scales is insufficient, is needed to reduce the negative trade balance and increase and diverse export.

Socio-economic or political processes taking place in CIS countries, especially in case of Russian example, clearly illustrates the fatal outcome which can be caused by a significant dependency on the Russian market, due to unpredictability of the market, EU association is one of the strongest tools which is a guarantee of export growth in EU member states.

From the diagram it is clear that despite the fact that Georgia is not a member of the CIS, it has very close and growing trade relations with member countries, exports have 
growing tendency with the EU and declining tendency toward the CIS countries, which is primarily the result of a Deep and Comprehensive Trade Agreement signed with the European Union, this promotes the development of the quality and competitive products in the country and the formation of a trading system compatible with the EU market.

\section{Research result}

As a result of some amendments Georgia has made to the way of Deep and Comprehensive Free Trade Areas (DCFTA), Georgian legislation is in line with EU' economic governance. According to the analysis carried out by the EU funded and independent research institutes, DCFTA will bring significant changes in the long-term prospects of Georgia's export-import, GDP growth, average wages and the purchasing power of the population, however, in the short term, many resources will be taken due to the details of the legislation and the short term static effects. Consequently, gradual implementation of approximation is recommended for better monitoring and predictability of short-term losses and development. The paper deals with the processes of economic integration, in particular the analysis of the trade-economic and financialcredit integration process, which shows that although recent foreign investments are characterized by a growing tendency in Georgia, but according to recent data, the International Business Compass 2018 survey (Friederiszick, et al., 2018), which deals with the investment environment of world countries, Georgia's position has not changed and is still in the 47 th place. Therefore, it is necessary to continue care of the investment policy of Georgia for the enhancement of the European integration process. It is necessary to take more efficient measures to attract European (and not just) investments. The decline in volume of foreign transactions (due to unpredictability of markets) significantly damages the Georgian economy. This is especially noticeable on the background of impaired negative balance sheet and depreciation of the national currency exchange rate. 


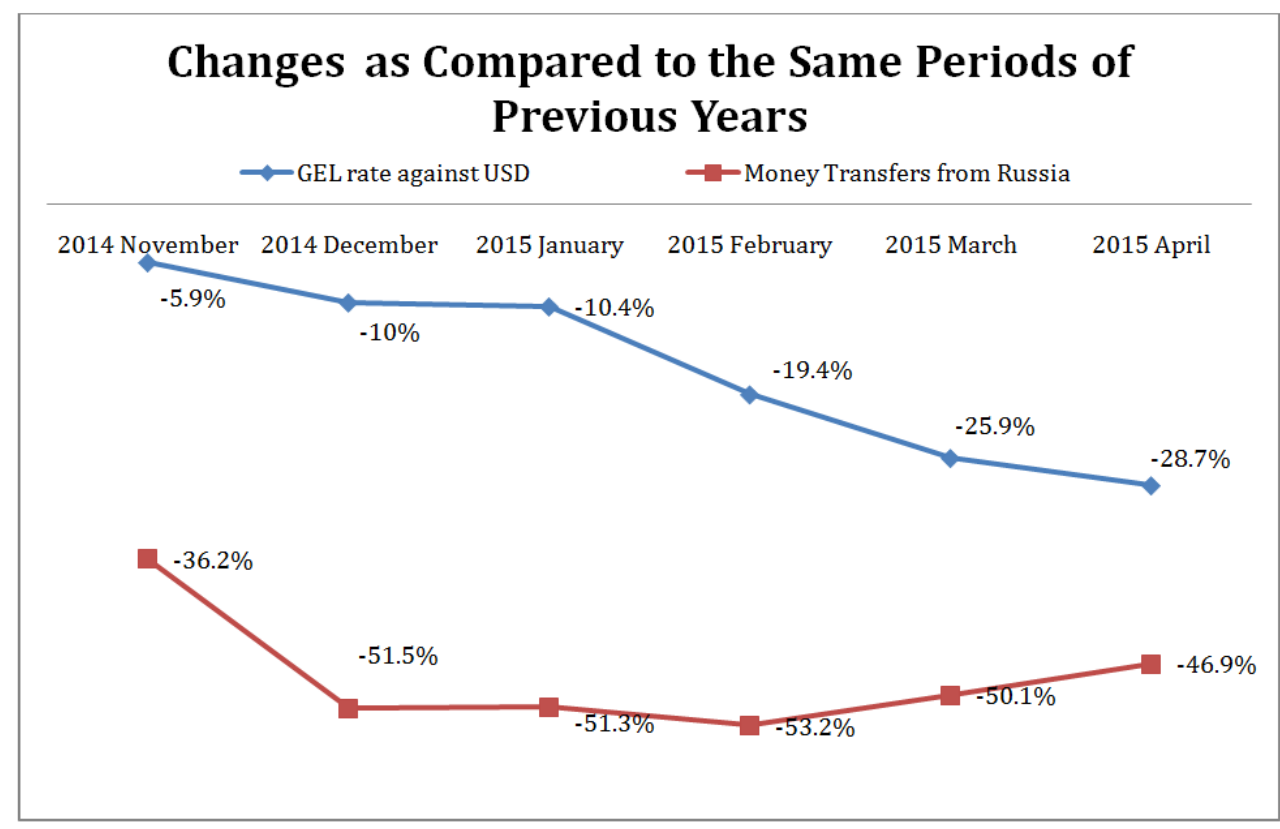

Diagram 6: Change of GEL rate against USD as compared to the change of net money transfers from Russia for the same periods of previous years

Source: National Bank of Georgia

Figure 11: The currency rate for the dollar and volume of foreign remittances made from Russia https://idfi.ge/en/theimpact-of-russian-money-transfers-on-stability-of-georgian-economy

The state should try to increase the share of EU countries in foreign money transfers , make money transfers as potential means of growth on the way of European integration. Despite the fact that Georgia is not a member of the CIS, it has very close and growing trade relations with member countries (Putkaradze, 2017). However, socio-economic or political processes in these countries, especially in the example of Russia (due to unpredictability of the market.), clearly reflect the fatal result caused by a significant dependency on the Russian market.

\section{Conclusions and suggestions}

- For the improvement and enhancement of the process of Georgia's European integration, it is necessary to maintain a permanent commitment to liberalize investment policy. It is necessary to take more efficient measures to attract European (and not just) investments.

- Money transfers are an important source of foreign currency in the country, which allows the purchase of imported goods, pay foreign debts, also country is more protected and less susceptible to foreign shocks. The state should try to increase the share of EU countries in foreign money transfers and turn on European integration, making money transfers as potential means of growth. The country should be less dependent on the unpredictable markets of the CIS countries. 
- Georgia has very close and growing trade relations with CIS member states, but in recent years exports are growing with the EU and declining tendency towards the CIS countries, deepening of the relationship with the EU and competitive products in the country and allows to create a trading system compatible with the EU market.

\section{References}

Abuselidze, G. (2012). Financial Market and Economic Sovereignty Compatibility Issues Under Globalization. IV International Conference Globalization and Sustainable Economic Development Prospects. ISBN 978-9941-17-599-2;

Abramishvili, N. (2016). European Integration and Business Enviroment in Georgia. European Journal of Sustainable Development, 5(1), pp. 91-96.

doi: 10.14207/ejsd.2016.v5n1p91;

Bartlett, W., Cuckovic, N., \& Jurlin, K. (2017). A Comparative Perspective on Institutional Quality in Countries at Different Stages of European Integration. Tijdscbrift Voor Economische En Sociale Geografie / Journal of Economic and Social Geography, 108(1), pp. 92-108. doi: 10.1111/tesg.12196.

Economic integration with the EU perspectives and opportunities; Tbilisi, 27-28 March, 2014; An international conference review. Retrieved from: http://www.economy.ge/uploads/news/giorgi_kvirikashvili/Concept_Note__DCFTA_Conference_-_geo.pdf

European Bank, (2006). Document of the European Bank for reconstruction and development, Strategy for Georgia, p.5. Retrieved from:

https://www.ebrd.com/downloads/about/policies/2006-11-21,_Strategy_for_Georgia-_English_web.pdf

European Bank, Project Summary Documents. Retrieved from:

https://www.ebrd.com/work-with-us/project-finance/project-summarydocuments.html? $1=1 \&$ filterCountry $=$ Georgia

Fischer, S., Sahay, R., \& Vegh, C. (1996). Stabilization and growth in transition economies: The early experience, IMF Working Paper 96/31, pg.9. Retrieved from:

http://mpra.ub.uni-muenchen.de/20631/1/JEP-IMF-WP.pdf

Forbes Georgia; 2018 year; With the money transferred by immigrants, the EU overcame Russia. Retrieved from: http:// forbes.ge/news/4451/evrokavSirma-ruseTs-gadauswro

Friederiszick, T., Stapke, M., \& Wolf, A. (2018). Bdo International Business Compass 2018. Update and Subject Focus: Energy and resource consumption. p.42. Retrieved from: https://www.bdo.dk/getmedia/d3484b74-77f6-4641-bb73a4f117ca93e8/BDO_IBC_2018_Executive_Summary_EN.pdf.aspx

Grahl, J., \& Teague, P. (2005). Problems of financial integration in the EU. Journal of European Public Policy, 12(6). doi: 10.1080/13501760500270679.

Grossman, E., \& Leblond., P. (2011). European financial integration: finally the

great leap forward? JCMS: Journal of Common Market Studies, 49(2). doi:10.1111/j.1468-5965.2010.02145.x.

Guiso, L., Jappelli, T., Padula, M., \& Pagano, M. (2004). Financial market integration and economic growth in the EU. Centre for studies in economics and finance. Dipartimento di scienze economiche Università degli studi di Salerno. Working paper, 118.

Hüning,H., Poensgen, k., Wolf, A. (2017). Update and in-depth look at openness. BDO International Business Compass 2017, p. 46. Retrieved from: https://www.bdo.ge/getattachment/Insights/Publications/BDO-IBC-International-BusinessCompass-2017/BDO_IBC17_EN_web.pdf.aspx?lang=en-GB

Institute for Development of Freedom of Information, (2015). The influence of money transfers from Russia's on economic stability. Retrieved from:

http://www.damoukidebloba.ge/c/news/rusetis_federaciidan

Ministry of Economy and Sustainable Development of Georgia, (2013). Foreign trade of 2013. Retrieved from:

http://www.economy.ge/uploads/files/sagareo_vachroba/2013_trade_turnover_final_1.pdf 
Ministry of Economy and Sustainable Development of Georgia, (2014). Georgia's Foreign Trade 2014. Retrieved from:

http://www.economy.ge/uploads/files/sagareo_vachroba/2014_FTT__28_01_2015.pdf

Ministry of Economy and Sustainable Development of Georgia, (2015). Georgia's Foreign Trade 2015. Retrieved from:

http://www.economy.ge/uploads/files/sagareo_vachroba/FTT'-_2015_6_month.pdf

Ministry of Economy and Sustainable Development of Georgia, (2016). External Trade of Georgia in 2016. Retrieved from:

http://www.economy.ge/uploads/files/sagareo_vachroba/Trade_turnover_2016.pdf

Ministry of Economy and Sustainable Development of Georgia, (2017). Georgian Foreign Trade 2017. Retrieved from:

http://www.economy.ge/uploads/files/2017/foreign_trade/trade_turnover_2017_12_month_final_11.pdf

McCreevy, C. (2006). Europe has made real progress on financial integration. Financial Times, 8 December.

Michael, E. (2016). Which model for Brexit? CEPS Special Report No. 147 / October 2016, p.6. Retrieved from: http://aei.pitt.edu/80225/1/SR147_ME_Which_model_for_Brexit.pdf

National Statistics Office of Georgia, (2017). Foreign Direct Investments in Georgia. Retrieved from:

http://geostat.ge/cms/site_images/_files/georgian/bop/FDI_2017Q4-2017-GEO-with\%20cover.docx.pdf

National Statistics office of Georgia, (2017). Foreign Trade in Georgia 2017 year. Retrieved from: http://www.geostat.ge/cms/site_images/_files/georgian/bop/FTrade_11_2017_GEOwith $\% 20$ cover.docx.pdf

Putkaradze, R. (2017). European Integration and Challenges of the Economy of Georgia. International Scientific-Practical Journal Globalization, the EU and Georgia. Retrieved from:

http://oaji.net/articles/2017/4783-1519280596.pdf

Vukovic, D. B., Hanic, E., \& Hanic, H. (2017). Financial integration in the European Union - the impact of the crisis on the bond market. Equilibrium. Quarterly Journal of Economics and Economic Policy, 12(2), 195-210. doi: 10.24136/eq.v12i2.10.

Vyklyuk, Y., Vukovic, D., \& Jovanović, A. (2013). Forex prediction with neural network: usd/eur currency pair. Actual problem of economics, 10(148). 